\title{
Lasiodiamesa (Podonominae, Chironomidae), first record of the genus from Slovakia
}

\author{
Ladislav Hamerlík ${ }^{1}$, Marta Veselská2, Milan Novikmec², Marek Svitok ${ }^{2}$
}

${ }^{1}$ Department of Biology and Ecology, Matej Bel University, Tajovského 40, SK-97401 Banská Bystrica, Slovakia.E-mail: ladislav.hamerlik@gmail.com

${ }^{2}$ Department of Biology and General Ecology, Technical University in Zvolen, T. G. Masaryka 24, SK96001 Zvolen, Slovakia.E-mail: novikmec@tuzvo.sk, svitok@,tuzvo.sk

\begin{abstract}
Here we report the first record of Lasiodimesa (Podonominae) in Slovakia. A single larva was collected in a small $\left(366 \mathrm{~m}^{2}\right)$ and shallow (max depth $0.6 \mathrm{~m}$ ) alpine pond located at 1,654 $\mathrm{m}$ a.s.l. in the High Tatra Mountains. Acidotolerant taxa such as Psectrocladius octomaculatus, Zalutschia tatrica, Synendotendipes sp. and Tanytarsus cf. gregarius were present in the community of the pond. Our finding indicates that the typical habitat of Lasiodiamesa larva is not necessarily a bog, but can also be a small acidic waterbody.

\section{Introduction}

Lasiodiamesa is a genus of the Podonominae subfamily confined to the northern Holarctic. The larva can be distinguished from other Podonominae by the elongate and bicolored procerci bearing strong apical setae, and by the mentum with high number (up to 14) of teeth. The labrum is less laterally compressed relative to other Podonominae (Cranston). Species of the genus are known from North America and Canada (4 species) and Fennoscandia, some with their southernmost distribution in Middle Europe. Out of the nine known species (Brundin 1966; Sæther 1967, 1969a; Wirth and Sublette 1970a), pupae are known for seven species (Brundin 1966a; Sæther 1969a). Here we present a record of a Lasiodimesa larva from an alpine pond in Slovakia. It is the first record of this genus in Slovakia.
\end{abstract}

\section{Material and methods}

The study pond is located in the Dolina Bielych plies valley (Fig. 1) in the north-eastern part of the Tatra Mts. (Slovakia, Central Europe), at $49.22227^{\circ} \mathrm{N} 20.22376^{\circ} \mathrm{E}$. The pond is surrounded by dense growths of

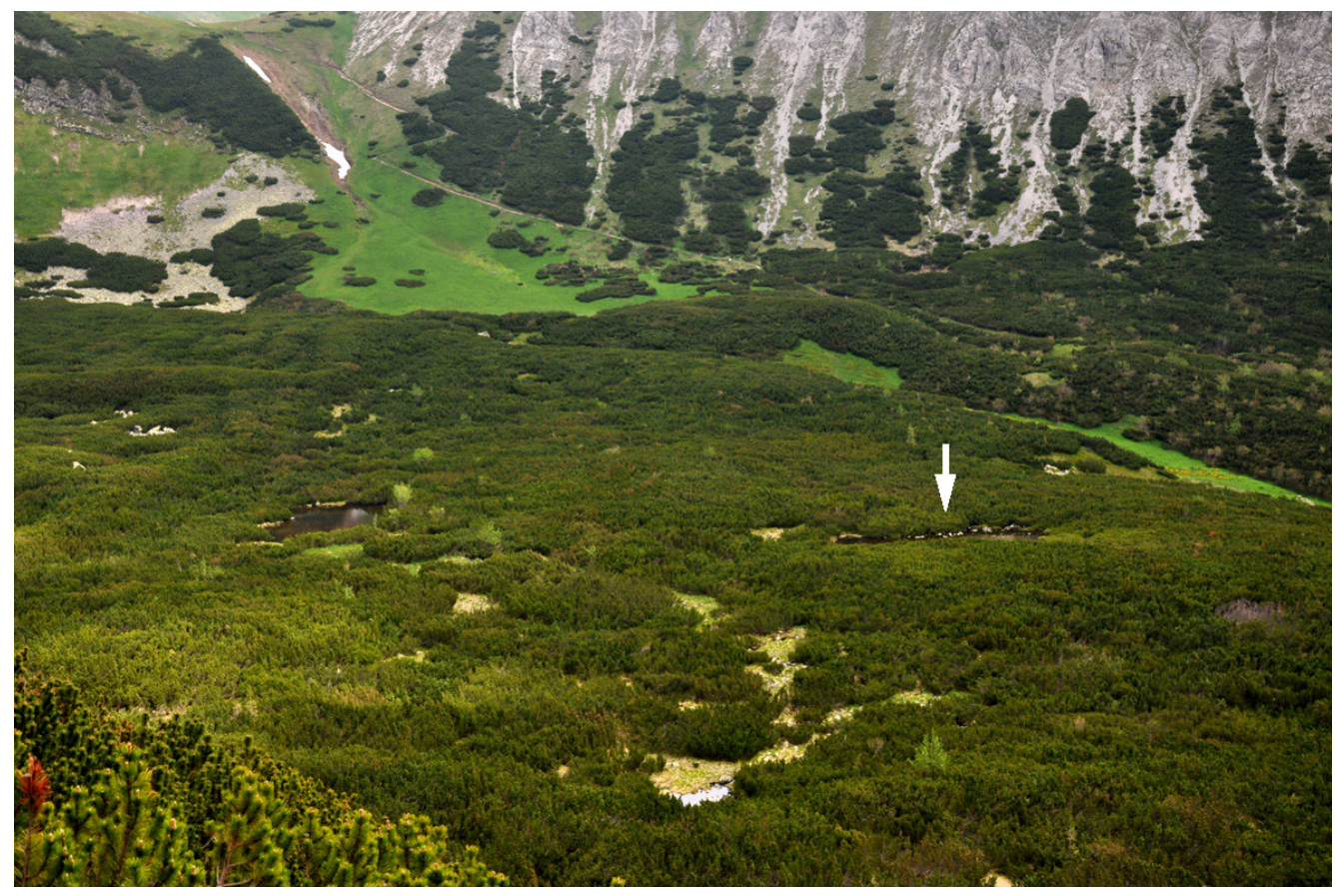

Figure 1. Location of the pond (indicated by arrow) in the Dolina Bielych plies valley where the larvae of Lasiodiamesa was recorded. 
dwarf pine (Pinus mugo). Basic characteristics of study pond are presented in Table 1 . The pond has no inlet, nor outlet and the substrate consists of 10 $\%$ megalithal $(>40 \mathrm{~cm}), 70 \%$ macrolithal $(>20-$ $40 \mathrm{~cm}$ ) and $20 \%$ organic mud.

A combination of drift sampling and the kicking technique was used to collect larvae and pupal exuviae. Preimaginal stages of chironomids were picked, mounted on permanent slides and identified using Sæther and Andersen (2013). The material is deposited at the Department of Biology and General Ecology, Technical University in Zvolen, Slovakia. For the list of other invertebrates recorded in the pond see Table 2 .

\section{Results}

Chironomidae: Podonominae: Lasiodiamesa sp.

Material examined: Material: 1 larva (4 July 2013, Fig. 2a-d) out of 650 specimens collected (Table 2), leg. M. Veselská, det. L. Hamerlík.

Distribution: Four species are known from the Palaearctic (Spies and Sæther 2015). The most common member of the genus is the Holarctic L. sphagnicola (Kieffer 1925) recorded in 9 European countries including Scandinavia and countries from Western to Eastern Europe. L. gracilis (Kieffer, 1924) is known from Finland, Sweden, Poland, The Netherlands and Czech Republic (Syrovátka and Langton 2015). One species is known from Scandinavia (L. armata Brundin 1966) and one from Germany and Norway (L. bipectinata Sæther 1967). From the Palaearctic only L. sphagnicola is known as larva. The degree of specific differences among larvae of the genus is uncertain (Sæther and Andersen 2013), thus it is not possible to classify our record to any of the Palaeartic species.
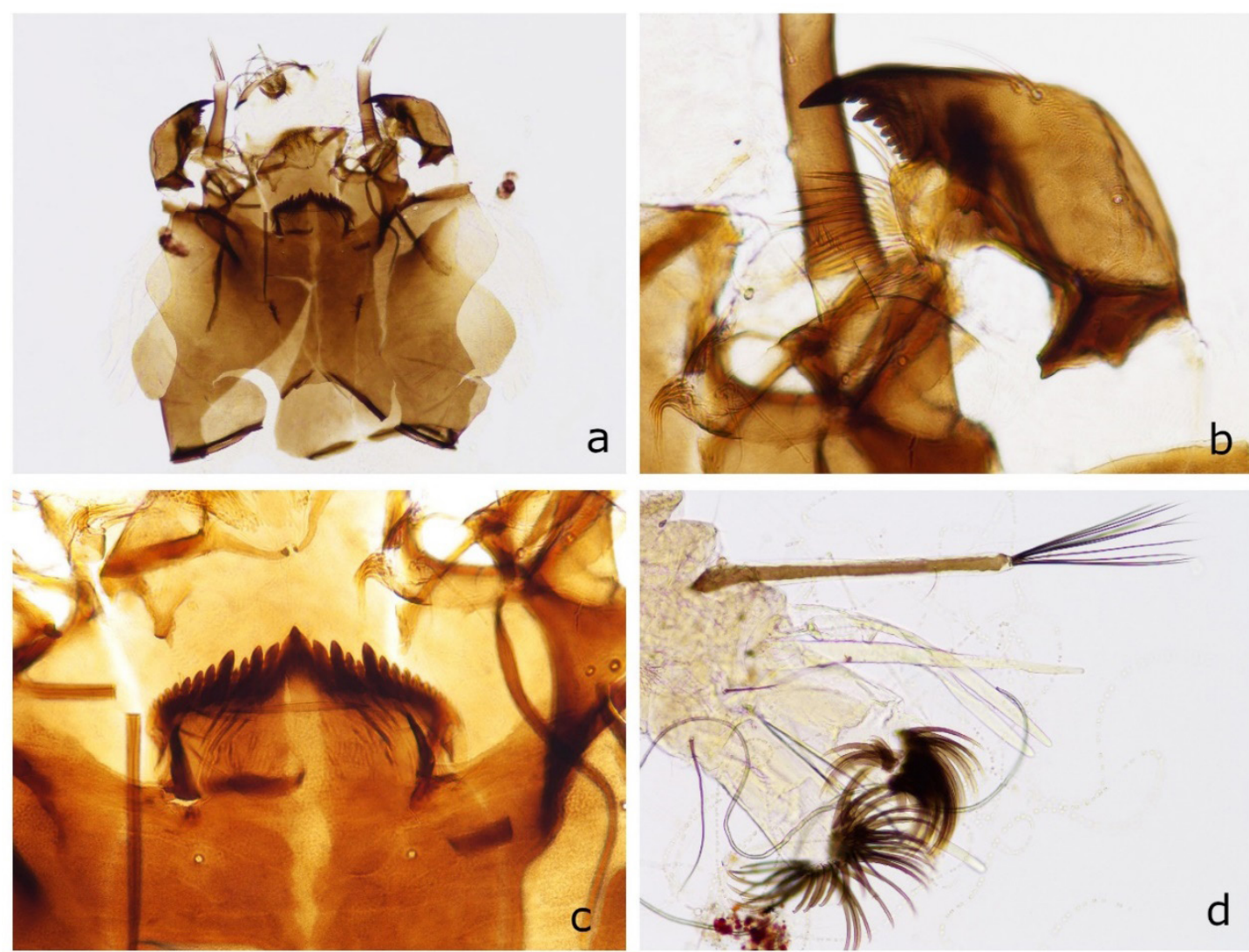

Figure 2. Photograph of the head (a), mandible (b), mentum (c) and anal end with procerci (d) of the recorded Lasiodiamesa larva. variables were recorded during the field works or determined in laboratory by analysis of water samples taken

\begin{tabular}{lc}
\hline Characteristic & Value \\
\hline Area & $368 \mathrm{~m}^{2}$ \\
Altitude & $1,654 \mathrm{~m}$ \\
Max. depth & $0.6 \mathrm{~m}$ \\
$\mathrm{pH}$ & 5.99 \\
Conductivity $\left(25^{\circ} \mathrm{C}\right)$ & $8 \mu \mathrm{S} \mathrm{cm}^{-1}$ \\
DOC & $5.727 \mathrm{mg} \mathrm{L}^{-1}$ \\
\hline
\end{tabular}

Table 1 . Basic physical, chemical and hydromorphologi-
cal characteristics of the surveyed pond. Environmental 
Ecology: Larvae of Lasiodiamesa live in bog waters and Sæther and Andersen (2013) state that in Central Europe immature stages are restricted to Sphagnum bogs. Interestingly, the site of our record in the Tatra Mts. is not a peat bog, however, it had slightly acidic water ( $\mathrm{pH}$ 5.99), and we assume that due to its small size it is extremely prone to $\mathrm{pH}$ changes, especially during the spring snow thaw. The community composition with multiple aciodotolerant taxa such as Zalutschia tatrica, Synendotendipes sp. and Tanytarsus cf. gregarius confirm the acidic character of the surveyed pond and indicates that the typical habitat of Lasiodiamesa larva is a small acidic waterbody, however, not necessarily a bog.

Table 2. List and counts of taxa recorded in the study pond. PE refers to taxa recorded only as pupal exuviae.

\begin{tabular}{ll}
\hline Taxon name & Abundance \\
\hline Hydracarina & \\
Hydracarina indet. & 1 \\
Heteroptera & 4 \\
Sigara nigrolineata (Fieber, 1848) & \\
Coleoptera & 3 \\
Agabus sp. & 4 \\
Hydroporus melanarius Sturm, 1835 & 24 \\
Hydroporus palustris (Linnaeus, 1761) & 89 \\
Hydroporus sp. & \\
Trichoptera & 6 \\
Limnephilus coenosus Curtis, 1834 & 1 \\
Oligotricha striata (Linnaeus, 1758) & \\
Diptera & 115 \\
Procladius (Holotanypus) spp. & 4 \\
Zavrelimyia sp. & 5 \\
Diamesa sp. & 27 \\
Corynoneura scutellata group & PE \\
Cricotopus (Isocladius) sp. & 109 \\
Psectrocladius (s. str.) octomaculatus Wulker, 1956 & 60 \\
Zalutschia tatrica (Pagast, 1935) & 28 \\
Micropsectra sp. & 11 \\
Synendotendipes sp. & 158 \\
Tanytarsus sp. & $\mathrm{PE}$ \\
Tanytarsus cf. gregarius (Kieffer 1909) & 1 \\
Lasiodiamesa sp. & \\
\hline & \\
\hline
\end{tabular}

\section{Acknowledgements}

This study was supported by the Slovak Scientific Grant Agency (VEGA), projects No. 1/0341/18 and 2/0030/17, as well as the Slovak Research and Development Agency, project number APVV-16-0236. We are grateful to Jiří Kopáček (Institute of Hydrobiology, Biology Centre of Academy of Sciences of the Czech Republic) for DOC analysis.

\section{References}

Brundin, L. 1966. Transantarctic relationships and their significance, as evidenced by chironomid midges. With a monograph on the subfamilies Podonominae and Aphroteniinae and the austral Heptagyiae. Kunglica Svenska Vetenskapsakademiens Handlingar 472 p.

Cranston P.S. http://chirokey.skullisland.info/genus/Lasiodiamesa/ (13.12.2019)

Bitušík, P. and Brabec, K. 2009. Chironomidae Newman, 1834. In: Jedlička, L., Kúdela, M. and Stloukalová, V. (eds). Checklist of Diptera of the Czech Republic and Slovakia. Electronic version 2. http:// zoology.fns.uniba.sk/diptera2009 
Sæther, O.A. 1967. Descriptions of Lasiodiamesa bipectinata spec. nov. and Parochlus kiefferi (Garrett) Brundin (Diptera: Chironomidae). - Beiträge zur Entomologie - Contributions to Entomology 17: 235249. DOI: https://doi.org/10.21248/contrib.entomol.17.1-2.235-249

Sæther, O.A., 1969. Some Nearctic Podonominae, Diamesinae and Orthocladiinae. - Bulletin / Fisheries Research Board of Canada 170: 154.

Sæther, O.A. and Andersen, T. 2013. The larvae of Podonominae (Diptera: Chironomidae) of the Holarctic Region - Keys and diagnoses. - In Andersen, T., Cranston, P.S. and Epler, J.H. (Eds) Chironomidae of the Holarctic Region - Keys and diagnoses. Part 1. Larvae. - Insect Systematics \& Evolution, Supplement 66: 29-38.

Spies, M. and Sæther, O.A. 2013. Fauna Europaea: Chironomidae. - Pape, T. and Beuk, P, (Eds.): Fauna Europaea: Diptera, Nematocera. Fauna Europaea version 2018.08, http://www.faunaeur.org.

Syrovátka, V. and Langton, P.H. 2015. First records of Lasiodiamesa gracilis (Kieffer, 1924), Parochlus kiefferi (Garrett, 1925) and several other Chironomidae from the Czech Republic and Slovakia. - CHIRONOMUS Journal of Chironomidae Research 28: 45-56. DOI: https://doi.org/10.5324/cjcr.v0i28.1953

Wirth, W.W. and Sublette, J.E., 1970. A review of the Podonominae of North America with descriptions of three new species of Trichotanypus (Diptera: Chironomidae). Journal of the Kansas Entomological society 43: 335-354. https://www.jstor.org/stable/25082345

Article submitted 17. December 2019, accepted by Torbjørn Ekrem 19. December 2019, published 20. December 2019. 